\title{
Survival into sixth decade after a Potts palliation for Tetralogy of Fallot, complicated by shunt-infective endocarditis and massive pulmonary embolism
}

\author{
Lucy Cosbey, ${ }^{1}{ }^{1}$ Tamara Naneishvili, ${ }^{2}$ Adrian Morley-Davies, ${ }^{2}$ Hefin Jones ${ }^{1}$
}

'Radiology Department, Royal Stoke University Hospital, Stokeon-Trent, UK

${ }^{2}$ Cardiology Department, Royal Stoke University Hospital, Stokeon-Trent, UK

\section{Correspondence to Dr Lucy Cosbey, \\ lucycosbey@gmail.com}

Accepted 22 March 2019

\section{DESCRIPTION}

A 56-year-old female with a background of Tetralogy of Fallot (TOF) and atrial flutter attended the accident and emergency department with a 14-week history of $12 \mathrm{~kg}$ weight loss and intermittently loose stools. With regards to the TOF, the patient underwent a Pott's shunt procedure at the age of 2 but never proceeded to have the corrective surgery at the age of 11 as her grandmother declined on her behalf. Previous CT thorax demonstrated classical findings of TOF and Pott's anastomosis (figure 1). Blood tests revealed raised inflammatory markers (white cell count $23 \times 10^{9} / \mathrm{L}$ and C-reactive protein $214.9 \mathrm{mg} / \mathrm{L}$ ), and three blood cultures were positive for Streptococcus mitis/S. oralis. Echocardiography showed a patent Potts shunt and no clinical evidence of endocarditis. The patient was treated for shunt-infective endocarditis with benzylpenicillin according to culture sensitivities and hospital protocol. Subsequently, she developed increasing shortness of breath and a CT Thorax, Abdomen and Pelvis, with contrast demonstrated an extensive filling defect within the pulmonary arterial system, including the pulmonary trunk and right main pulmonary artery, with further extensive involvement of the right upper, middle and lower lobe arteries, most likely due to extensive pulmonary embolism. The CT also showed a right-sided pleural effusion and pulmonary infarction of the right, middle and lower zones (figure 2). The patient remained anticoagulated throughout admission. Due to her critical condition, the risks of a surgical embolectomy outweighed the risks of conservative management. The patient developed hospital-acquired pneumonia, but unfortunately, despite antibiotic treatment, continued to deteriorate and passed away on day 13 of admission.

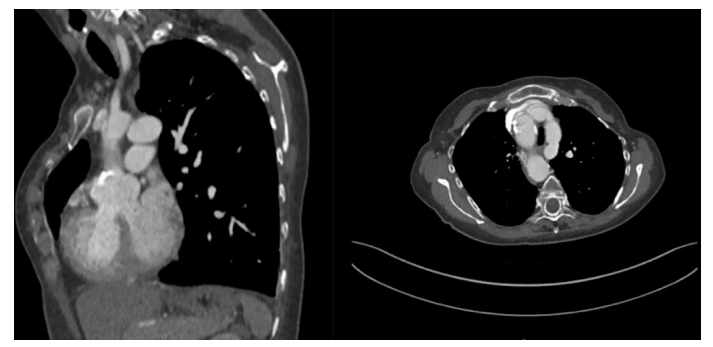

Figure $1 \mathrm{CT}$ images showing features of Tetralogy of Fallot (over-riding aorta, ventricular septal defect and equal hypertrophy of the left and right ventricles) and Potts shunt.

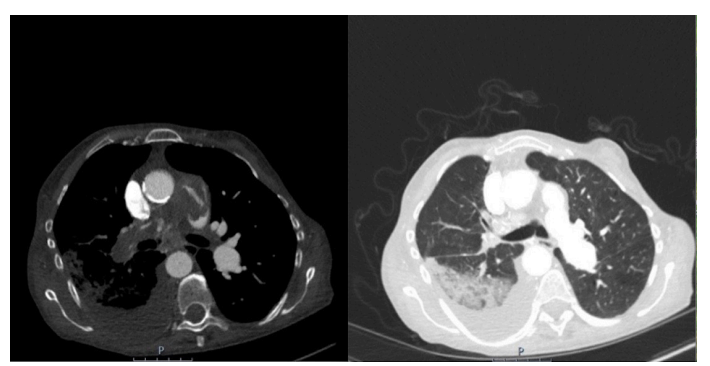

Figure $2 \mathrm{CT}$ images showing extensive main pulmonary artery and right pulmonary artery thrombus/vegetation with lung window showing typical pulmonary infarct and right pleural effusion.

Survival into late adulthood is rare in patients with unrepaired TOF; $66 \%$ live to age 1 year, $49 \%$ to age 3 years and $24 \%$ to age 10 years. ${ }^{1}$ There is only one reported case of a patient who lived into the seventh decade with an unrepaired TOF and palliative Potts anastomosis. ${ }^{2}$ Patients with TOF who have undergone palliative procedures including Potts shunt have an improved survival rate compared with unrepaired TOF cases; $11 \%$ are alive at age 20 years, $6 \%$ at age 30 years and $3 \%$ at age 40 years. ${ }^{3}$ Patients' with TOF and Potts anastomosis have an $8 \%$ risk of infective endocarditis. ${ }^{4}$ The frequency of infective endocarditis complications depends on the infecting pathogen, duration of disease before therapy and type of treatment. A retrospective study showed a $44 \%$ incidence of echocardiogram-negative infective endocarditis, which may be caused by a variety of organisms and

\section{Learning points}

- This case is of clinical interest as it highlights the rarity of survival into the sixth decade without operative correction of tetralogy of Fallot and the rare complications of shunt endocarditis and pulmonary embolism.

- Congenital heart disease with high-velocity shunts is significantly correlated with an increased incidence of infective endocarditis of both native heart tissues and shunts.

- A high incidence (44\%) of echonegative infective endocarditis highlights the need to embrace the term: 'echo-negative endocarditis' in patients with compatible clinical picture, damaged heart valves and positive blood cultures. 
occurs in elderly patients or on damaged valves. ${ }^{5}$ Systemic embolisation in patients with infective endocarditis occurs in $22 \%$ to $50 \%$ of cases, however, it is often difficult to assess the true incidence of complications because the published reviews in literature are frequently based on retrospective analysis and different diagnostic criteria. ${ }^{6}$

Contributors LC and TN collected and analysed the data from the patient's medical notes, and discussed and reflected on the case with both cardiology and radiology consultants. Following a literature review, LC and TN composed the article in accordance with the BMJ 'images in' template including anonymising any identifiable patient details. The patient was under the care of AM-D, cardiology consultant. HJ was the reporting radiologist of the patient's CT scans and kindly provided the anonymised $\mathrm{CT}$ images for publication. All authors have reviewed the final draft including figures prior to submission, hence, meeting all four ICMJE criteria for authorship.

Funding The authors have not declared a specific grant for this research from any funding agency in the public, commercial or not-for-profit sectors.
Competing interests None declared.

Patient consent for publication Not required.

Provenance and peer review Not commissioned; externally peer reviewed.

\section{REFERENCES}

1 Bertranou EG, Blackstone EH, Hazelrig JB, et al. Life expectancy without surgery in tetralogy of Fallot. Am J Cardiol 1978;42:458-66.

2 Oosterhof T, Jacobs M, Cramer MJ, et al. Survival into seventh decade after a potts palliation for tetralogy of Fallot. Congenit Heart Dis 2007;2:55-7.

3 Viswanathan N. A rare case of tetralogy of fallot (TOF) with Potts shunt -4 th Decade of survival. University journal of medicine and medical sciences 2016;2.

4 Kaplan EL, Rich H, Gersony W, et al. A collaborative study of infective endocarditis in the 1970s. Emphasis on infections in patients who have undergone cardiovascular surgery. Circulation 1979;59:327-35.

5 Hershman-Sarafov M, Paz A, Potasman I. Echo-negative endocarditis: analysis of 538 consecutive transesophageal echocardiographies. Open Forum Infect Dis 2016;3:1105

6 Mocchegiani R, Nataloni M. Complications of infective carditis. Cardiovascular and Haematologocal disorders drug targets 2009;9:240-8.

Copyright 2019 BMJ Publishing Group. All rights reserved. For permission to reuse any of this content visit https://www.bmj.com/company/products-services/rights-and-licensing/permissions/

BMJ Case Report Fellows may re-use this article for personal use and teaching without any further permission.

Become a Fellow of BMJ Case Reports today and you can:

- Submit as many cases as you like

- Enjoy fast sympathetic peer review and rapid publication of accepted articles

- Access all the published articles

- Re-use any of the published material for personal use and teaching without further permission

For information on Institutional Fellowships contact consortiasales@bmjgroup.com

Visit casereports.bmj.com for more articles like this and to become a Fellow 